\title{
An Overview of Models of Bilingual Education
}

\author{
Anna Hurajová \\ Faculty of Mass Media Communication, University of Ss. Cyril and Methodius, Trnava, The Slovak Republic \\ ahurajova@yahoo.com
}

\section{Doi:10.5901/mjss.2015.v6n6s1p186}

\begin{abstract}
Bilingual education is considered to be an effective way of learning a new language and in many countries of the world, it represents an increasingly popular pedagogic approach. In Europe, bilingual education using predominantly the Content and Language Integrated Learning (CLIL) methodology has evolved as a response to the commonly recognized need for the development of plurilingual competence. In this article, we present forms of bilingual education that are recognized according to worldwide research as well as varying purposes behind using different languages as the medium of instruction in schools. We begin by outlining the emergence of bilingual education in general and by stating the different purposes that lead to the occurrence of various actual school systems of bilingual education. The paper focuses on a taxonomy of common patterns of bilingual education, based on worldwide research sources.
\end{abstract}

Keywords: bilingual education; transitional model; maintenance model; enrichment model; immersion; submersion; CLIL; critical thinking

\section{Introduction}

Based on the fact that about 75 per cent of the world is bilingual, a bilingual education has become a widespread approach used throughout the world. It may be implemented in different ways, with different educational goals in different countries. Bilingual education has been an issue in education for a long time. Lack of motivation and interest in the taught subject are common phenomenon in many classrooms, thus making traditional target language teaching is not as successful as it might be expected by teachers. Students do not seem to see any use in learning a foreign language, the situation being very similar in content teaching. As recent research indicates, it is CLIL that offers opportunities how to improve this situation, with below-average and above-average students benefiting from exposure to it. Moreover, demographic situation in many countries of the world shows evidence that in the near future, there will be a greater need for bilingual education.

\section{Defining Bilingual Education}

Bilingual education (both formal and informal) is education provided in at least two languages (Pokrivčáková, 2013). However, the topic is much more complicated as bilingual education often means different things to different people. For some, bilingual education may mean teaching two languages as independent school subjects, for others it may be teaching a foreign language as a separate subject along with another subject taught in that foreign language. In some other cases, bilingual education can be defined as teaching bilingual learners through the medium of one language, with bilingualism not being promoted at all and thus the schooling itself being monolingual (Pokrivčáková, 2013). In different countries, the term bilingual education takes on different meanings. In some countries, e.g. in the USA, bilingual education is perceived as being connected with the sphere of minorities education, immigrants and children from socially disadvantaged families. The fact that part of the teaching time is not realized in the majority language (English) but in the children's mother tongue (nowadays mainly in Spanish) is considered to be the reason for a lower quality of education of these groups and the reason why language minority students would fall behind their peers (Pokrivčáková, 2013). On the contrary, in Europe, multilingualism and bilingual/multilingual education are perceived as an extremely positive value, enriching the culture of individuals and nations (Pokrivčáková, 2013).

A commonly agreed definition of bilingual education is that by Cohen saying that „bilingual education is the use of two languages as media of instruction for a child or a group of children in part or all of the school curriculum" (Cohen, 1975). Bilingual education scholars also believe that it is impossible to separate language and culture; therefore, as language is the basis of any culture, a very strong factor of bilingual education is bicultural education and learning a 
language is also learning about a certain culture (Buschenhofen, 1980).

\section{Main Aims of Bilingual Education}

\subsection{Goals of Bilingual Education}

In some education systems, bilingual education is a tool for weakening of learners' original bilingualism and development of general and academic literacy only in one (state) language, such as in countries with a high number of immigrants like the USA, Great Britain or China. On the other hand, in European context, the emphasis is put on systematic and targeted development of general as well as academic literacy of learners (Pokrivčáková, 2013). In this paper, bilingual education is understood as a term comprising any system of education in which the curriculum is presented to students in two languages.

According to (Malarz, Bilingual Education), the goals of bilingual education can be organized into the following four categories: cognitive development, affective development, linguistic growth and cultural enrichment. However, controversies arise among scholars as to which of these goals should be recognized as primary goals. For some experts, cognitive and affective development should be at the core of the bilingual programme, whilst for the others it is the linguistic goals that should be primary. Acquisition of English language is emphasized in bilingual programmes with linguistic and cultural maintenance, but the value of linguistic and cultural diversity is promoted, too. Although transition to the mainstream and maintenance of the native culture are both important, they should not be the central theme of a bilingual programme (Malarz, Bilingual Education).

Recently, the idea of critical thinking development has commonly been expressed by educators teaching in bilingual education programmes. Critical thinking thus represents one of the key competences in fulfilling the aims of contemporary education. The result of a successful critical thinking implementation into education is an ability to identify important facts and connections in a variety of information and to formulate opinions and solutions (Petranová, 2011). One of the contemporary areas of not only bilingual education, in which critical thinking competence may well be developed is media education (Petranová, 2011; Kačinová, 2012; Plencner, 2014). The area of critical thinking development is also mentioned in (Kučerková et al., 2013; Zárubová, 2010).

\subsection{Languages in Bilingual Education}

Pokrivčáková (2013) provides the possible combinations of languages applied in bilingual education:

Table 1: Language combinations in bilingual education

\begin{tabular}{|l|l|}
\hline Combination & Explanation \\
\hline $\mathrm{L} 1+\mathrm{L} 2$ & $\begin{array}{l}\text { instruction that combines L1 (a mother language; the first language, a native language) with L2 (a second } \\
\text { language; the language of instruction that is not a learner's mother language but is used as an official, state } \\
\text { language in the country) }\end{array}$ \\
\hline $\mathrm{L} 1+\mathrm{FL}$ & $\begin{array}{l}\text { instruction given in both L1 and FL (a language that is neither a learner's mother language nor an official language } \\
\text { used in the country) }\end{array}$ \\
\hline $\mathrm{L} 2+\mathrm{FL}$ & instruction provided in L2 and FL \\
\hline $\mathrm{FL} 1+\mathrm{FL} 2$ & $\begin{array}{l}\text { instruction given in two different foreign languages that are neither a learner's mother language nor an official } \\
\text { language used in the country }\end{array}$ \\
\hline
\end{tabular}

What all bilingual educational programmes have in common is that it is two languages that are used as media of instruction in educational contexts. The focus of language learning is not solely linguistic, but it is also connected with academic achievement in the subject areas and communication within the academic institution (de Mejía, 2002). This is in contrast with language intensification programmes where there is in general no integration of foreign or second language teaching and learning with the aim of building knowledge in other content areas - the emphasis is put on linguistic aspects of the foreign language (de Mejía, 2002).

Bilingual education is "a simplistic label for a complex phenomenon“ (Baker, 2011). However, there are different types of bilingual education depending on whether such education uses two languages or only a second language, whether bilingualism is the aim in the classroom or whether bilingual children are only present in the classroom, but bilingualism is not promoted in the curriculum. One of the differences lies in the aim of bilingual education. Based on the 
scientific discussions, the aims of the different forms of bilingual education can be very different (Baker, 2011). Ferguson et al. in (Baker, 2011) lists examples of the varying aims of bilingual education, such as assimilation of individuals or groups into mainstream society, preserving ethnic and religious identity, enabling people to communicate with the outside world and unifying a multilingual society - let us mention only some of them.

\section{Basic Models of Bilingual Education}

In the literature of bilingualism, three basic models of bilingual education are recognized: the transitional model, the maintenance model and the enrichment model, each of them describing different programme goals with respect to educational contexts, relationships of majority and minority language speakers and the sequencing of the languages as media of instruction within the programme (de Mejía, 2002).

\subsection{The Transitional, Maintenance and Enrichment Model}

When the aim is to shift the child from the home, minority language, to the dominant, majority language, with the result of social and cultural assimilation, this type is referred to as transitional bilingual education. Another aim may be fostering the minority language in the child, with the strengthening cultural identity, e.g. by preserving heritage languages in heritage language programmes. This type of bilingual education is referred to as maintenance bilingual education (Baker, 2011). An enrichment model of bilingual education has many characteristics in common with maintenance model but it takes the latter one a step further by aiming not only maintaining the first language but also developing and extending it (de Mejía, 2002). This leads to cultural pluralism and linguistic diversity (Baker, 2011).

Some types of bilingual education promote additive bilingualism when a second language is added to a mother tongue and the result are students who are bilingual; however, other types of bilingual education promote subtractive bilingualism when students are instructed in both their mother tongue and a second language. Educational programs supporting additive bilingualism are referred to as strong, whereas those which promote subtractive bilingualism are referred to as weak (García, 1996).

\subsection{Strong and Weak Forms of Bilingual Education}

Some types of bilingual education promote additive bilingualism when a second language is added to a mother tongue and the result are students who are bilingual; however, other types of bilingual education promote subtractive bilingualism when students are instructed in both their mother tongue and a second language. Educational programs supporting additive bilingualism are referred to as strong, whereas those which promote subtractive bilingualism are referred to as weak (García, 1996). Baker (2000) provides the four main types of bilingual schools which are labelled as ,strong' forms of bilingual education: Dual Language Schools found in the United States, International schools with English usually being a dominant language, Heritage Language Schools for language minority children and immersion schools in Canada, subsequently appearing in Europe and Asia.

With the promotion of two or more languages as well as biliteracy and biculturalism being attempted to enrich children, particularly linguistically, these bilingual schools may serve as examples of enrichment bilingual education. Language acquisition in the immersion, heritage and dual educational programmes happens through a second language that is used as a medium of instruction, which is called content-based second language instruction in the USA while in Europe it is referred to as CLIL (Content and Language Integrated Learning) (Baker, 2011).

A) Dual Language schools: In Dual Language Schools which are increasingly found in the United States, two languages are used approximately equally in the curriculum with the aim of children becoming bilingual and biliterate (Baker, 2000). Each class contains an equal number of language majority and language minority children. A language balance close to $50 \%: 50 \%$ is the aim; however, it is not always achieved - the amount of time spent learning through each language varies from school to school. Only one language is used in each period of instruction, which is similar to content-based teaching where students are taught parts of the curriculum through English and not just English as a mere language (Baker, 2011). A central idea in Dual Language schools is language separation and compartmentalization. In practice, it means that in each period of instruction, only one language is used, with language boundaries being established in terms of time, curriculum content and teaching (Baker, 2000). It is important to decide when to teach through each language - the most frequent preferences are to use the two languages on alternate days or to use different languages in different lessons with regular alternations to ensure both languages are used in the curriculum. Although 
language boundaries are established so that different parts of the curriculum are taught in different languages, a dangerous situation may occur when the majority language becomes associated with more prestigious and ,modern' subjects while the minority language is used to teach less prestigious subjects. Such division may affect the status of the languages in the eyes of the pupils, their parents and society (Baker, 2000).

B) International schools: International schools can be found throughout the world, mostly in large cities of more than 80 countries. In these schools, fees are paid to receive private, selective, independent education (Baker, 2000). De Mejía (de Mejía, 2002) provides two basic types of international schools, one designed to be national schools for children who are away from home, and the other based on principles of global education serving global human development arising from, e.g. the United Nations. Some of the children in these schools have parents in the diplomatic service or multinational organizations and other children come from the areas whose parents want them to receive an internationally recognized education. Over the last 20 years, there has been a greater diversity among the international schools population including not only non-native children but also local children being sent to international schools by their parents to increase slumping enrolment figures. According to Murphy in (de Mejía, 2002), international schools are classified as monolingual with only one official language of instruction in school or as bilingual/multilingual when two or more languages, of the host country and the other countries, are taught and incorporated in the curriculum. One language of the school is usually English. In some schools, the second language is taught only as a language, while in other schools, the second language can be used as a medium to teach part of the curriculum (Baker, 2000). In general, the languages in international schools are majority languages with international prestige with minority languages being rarely found. The curriculum reflects America, British and the local curricular tradition with the majority of teaching staff from Britain and the USA. Some of the advantages of such schools are small class size, motivated students and international spirit among the learners; on the other hand, an extremely high level of learners'mobility can be seen as a disadvantage (de Mejía, 2002).

C) Heritage Language Bilingual Education: Lastly, there is Heritage Language Bilingual Education where language minority children use their native, ethnic, home or heritage language in the school as a medium of instruction and the goal is full bilingualism (Baker, 2000). As mentioned earlier in this paper, the bilingual education aiming to protect indigenous languages in heritage language programmes is referred to as maintenance bilingual education. Generally, heritage or maintenance language education represents the education of language minority children through their minority or indigenous language in a majority language society.

\subsection{Immersion and Submersion Bilingual Education}

Immersion education, deriving from a Canadian educational experiment, differs from other types of bilingual and foreign language provision in some core features. Firstly, the second language is a medium of instruction (de Mejía, 2002). Issuing from the idea that a first language is acquired relatively subconsciously, the focus is on the content rather than the form of the language (Baker, 2000). Moreover, students enter the programme with similar level of the second language knowledge and there is enough support for their first language within the curriculum. Secondly, immersion programs aim at additive bilingualism, which means that they acquire a second language at no cost to their home language. This is in contrast to subtractive bilingual programmes where the home language is replaced by the second language (Baker, 2000). Thirdly, contact with the second language is mostly restricted to the classroom and the classroom culture is that of the local community, not the target language community (de Mejía, 2002). Furthermore, immersion education possesses certain variations in terms of age at which children start the programme and in terms of the amount of time spent in immersion in a day (Baker, 2000). In terms of age, immersion ranges from early immersion starting at the kindergarten or infant stage to late immersion at secondary level. The degree of immersion ranges from total, with early total immersion being the most popular programme, to partial providing a certain percentage of immersion in the second language throughout junior schooling.

A completely different approach to learning of a language is s seen in submersion education. Submersion education describes education for language minority children who are placed in mainstream schools. However, no school calls itself a 'submersion school', 'mainstreaming' is the more usual label (Baker, 2011). Baker (2011) uses a metaphor when language minority students are thrown into water and are expected to learn to swim as quickly as possible without the help of special swimming lessons with the language of the "swimming pool" being the majority language and not the home language of the child. The language minority students will be taught in the majority language and both teachers and students will be expected to use exclusively the majority language in the classroom. The basic educational aim of 
mainstreaming is assimilation of language minority speakers, particularly in the countries where there has been immigration (e.g. the USA, the UK). Dealing with bilingual children, this kind of education is bilingual, but it is the majority language that is the medium and the aim is monolingualism, not bilingualism (Baker, 2011). As Baker (2011) further points out, „mainstream education rarely produces functionally bilingual children“; the typical outcome for the language majority would be only a limited knowledge of a foreign language. Submersion or mainstream education is often associated with subtractive bilingualism, where a minority language speaker has to 'sink or swim' at school without any institutional support (de Mejía, 2002).

\section{Conclusion}

This paper shows the basic types of bilingual education that are recognized according to worldwide research. Bilingual education is briefly introduced as well as the different purposes behind using different languages as the medium of instructions in schools. Research on bilingualism suggests that some purposes for choosing languages used in education may be better than the other ones in terms of ethics as well as pedagogy. Analyzing the diverse purposes for the choice of languages that appear in schools can improve the understanding of bilingual educational systems, and possibly suggest improvements in terms of bilingual educational process.

\section{References}

Baker, C. (2000). A Parents' and Teachers' Guide to Bilingualism. Clevedon: Multilingual Matters Ltd., 218 p.

Baker, C. (2011). Foundations of Bilingual Education and Bilingualism", Clevedon: Multilingual Matters, $480 \mathrm{p}$.

Buschenhofen, P. (1980). Trendy experimentation or cultural enrichment? Journal of Multilingual \& Multicultural Development, vol. 1, no. 4, pp. 303-312.

Cohen, A. (1975). A Sociolinguistic Approach to Bilingual Education. Rowley, Mass.: Newbury House.

García, O. (1996). Bilingual Education. The Handbook of Sociolinguistics, F. Coulmas Ed. Oxford: Blackwell Publishers, 544 p.

Kačinová, V. (2012). Terminological Problems of Media Education. Communication Today, vol. 3, no. 2, pp. 24-38.

Kučerková, M., Kučerka, D., Rusnáková, S., Husár, S. and Hrmo, R. (2013). Research in Engineering Pedagogy", International Conference on Interactive Collaborative Learning (ICL), Kazan, Russia: The Institute of Electrical and Electronic Engineers, pp. 30-35.

Malarz, L. Bilingual Education: Effective Programming for Language-Minority Students. http://www.ascd.org/publications/curriculum_ handbook/413/chapters/Bilingual_Education@_Effective_Programming_for_Language-Minority_Students.aspx.

De Mejía, A. (2002). Power, Prestige, and Bilingualism: International Perspectives on Elite Bilingual Education. Clevedon: Multilingual Matters, $325 \mathrm{p}$.

Petranová, D. (2011). Does media education at schools develop students' critical competences? Communication Today, vol. 2, no. 1, pp. 66-82.

Plencner, A. (2014). Critical Thinking and the Challenges of Internet. Communication Today, vol. 5, no. 2, pp. 4-18.

Pokrivčáková, S. (2013). Bilingual Education in Slovakia: A Case Study. Journal of Arts and Humanities, vol. 7, no. 5, pp. 10-19.

Zárubová, H. (2010) .Súčasné prístupy a metódy vo výučbe cudzích jazykov. Perspektívy výučby cudzích jazykov pre 21. storočie, Trnava: UCM v Trnave, pp. 123-132. 